\title{
DINAMICA SECURITĂȚII ÎN NORDUL AFRICII ȘI ÎN REGIUNEA SAHEL ÎN PRIMA PARTE A ANULUI 2021
}

Dr. Crăișor-Constantin IONIȚ $\breve{A^{*}}$

Prima jumătate a anului 2021 a fost caracterizată de continuarea răspândirii virusului Sars-CoV-2 pe întreg continentul african, de încercările susținute ale ONU și ale puterilor regionale de a implementa acordul de pace în Libia și de a menține situația de securitate sub control, precum și de creșterea numărului de migranți ilegali către Europa.

Pandemia de COVID-19 nu a dus la reducerea acțiunilor teroriste din regiunea Sahel și nici nu a stopat valul de mici ambarcațiuni cu imigranți către Spania și Italia dinspre Africa. Dar pandemia de coronavirus a determinat închiderea multor frontiere africane, aducând economia țărilor respective în pragul falimentului și deteriorând situația umanitară din Nordul Africii și a regiunii Sahel.

Comunitatea internațională controlează cu greu situația din zonă, indeosebi criza umanitară și migrația ilegală, fapt care afectează grav securitatea din proximitatea sa.

Cuvinte-cheie: Nordul Africii; zona Sahel; război civil; guvern interimar de uniune națională; terorism transfrontalier; migrație ilegală; ECOWAS; Operația Barkhane.

\section{Introducere}

Multiplele conflicte și acțiuni teroriste care au avut loc pe parcursul anului 2020 și continuă să se desfășoare pe întreg teritoriul african și în acest an au

* Colonel (r) dr. Crăișor-Constantin IONIȚA este cercetător ştiinţific gradul III în cadrul Centrului de Studii Strategice de Apărare și Securitate, Universitatea Națională de Apărare „Carol I”, București. E-mail: ionita.constantin@unap.ro 
exacerbat pandemia de coronavirus în regiune, ducând la apariția unei așa-zise tulpini africane și la îngreunarea controlului aplicării măsurilor anti-COVID-19 la nivelul guvernelor țărilor africane. Apariția și răspândirea pandemiei de COVID-19 în zonele conflictelor sângeroase și a celor de criză a crescut insecuritatea, forțând o parte din populația civilă să se refugieze în zone mai stabile și a îngreunat simțitor impunerea sancțiunilor, luarea măsurilor contrateroriste sau desfășurarea operațiilor umanitare. Au existat pierderi umane și distrugeri de facilități ale organizațiilor umanitare, îndeosebi în Mozambic, Burkina Faso, Congo și Somalia. De asemenea, există riscul reapariției foametei în nord-estul Nigeriei, părți din regiunea Sahel și Sudanul de Sud.

Sfârşitul anului 2020, în Nordul Africii și în regiunea Sahel, a fost marcat de semnarea, la 23 octombrie 2020, a unui acord fragil de încetare a focului între părțile beligerante libiene și sponsorii internaționali ai acestora, urmat de stabilirea unui guvern interimar care să organizeze primele alegeri libere și democratice în Libia, în luna decembrie a lui 2021. Cea mai mare provocare pentru guvernul libian de uniune națională o reprezintă implementarea acordului de încetare a focului, îndeosebi prin luarea tuturor măsurilor de îndepărtare a mercenarilor străini care au luptat alături de o parte sau de alta a beligeranților, precum și realizarea unui plan care să unească diferitele părți ale Libiei aflate sub conducerea uneia sau alteia dintre părți. Până în prezent, embargoul impus de ONU privind interzicerea traficului ilegal cu arme în zonă s-a dovedit ineficient, diplomații din toată lumea asociind uciderea președintelui Ciadului, Idress Deby, la 19 aprilie 2021, cu un grup de rebeli antrenați și dotați cu arme în Libia. Frica cea mare a acestor diplomați este ca ceea ce s-a întâmplat în Ciad să nu se repete în provincia Sahel și apoi să se răspândească în Cornul Africii, Sudan, Sudanul de Sud, Niger, Etiopia, Republica Centrafricană și chiar Mozambic, dacă nu se întreprinde nicio acțiune eficace în zonă ${ }^{1}$.

De asemenea, jumătatea anului 2020 a fost marcată de o lovitură de stat în Mali, soldată cu înlăturarea de la putere a președintelui Ibrahim Boubacar Keita de către o juntă militară condusă de colonelul Assimi Goita. Ulterior, sub presiunea Comunității Economice a Statelor Vest-Africane (ECOWAS), către sfârșitul anului a fost instalat un guvern de tranziție, condus de președintele interimar colonel (r) Bah N'Daw, avându-l pe colonel Goita drept vicepreședinte. Dar, în luna martie 2021 și acest guvern a fost răsturnat, președintele interimar și prim-ministrul fiind arestați, iar colonelul Goita a preluat din nou conducerea guvernului, fiind ales președinte interimar al țării la 7 iunie 2021. În contrapartidă, la Summitul ECOWAS din 29 mai 2021, șefii de stat și de guvern africani au decis suspendarea calității de

\footnotetext{
${ }^{1}$ Edith M. Lederer, „UN focuses on demand to repatriate foreign fighters in Libya”, Associated Press News, 30 aprilie 2021, URL: https://apnews.com/article/united-nations-libya-europe-africa-middleeast-5746eb32c1f3ac676d8f37dacec3213c, accesat la 15.05.2021.
} 
membru al Mali din blocul lor. Aceeași măsură a luat-o și Uniunea Africană (AU), iar Franța și-a suspendat cooperarea militară cu junta maliană. ${ }^{2}$

Situația de securitate din Republica Centrafricană continuă să se înrăutățească, fiind caracterizată de încălcări repetate ale acordului de pace semnat în februarie 2019 între grupurile de rebeli și guvernul centrafrican, prin violări ale drepturilor omului și ale Dreptului Internațional Umanitar - taxare ilegală, abuzuri sexuale, jafuri de tot felul, trafic ilegal cu arme și trecere clandestină peste graniţă a luptătorilor străini, armelor și resurselor naturale. Chiar dacă, în luna decembrie a anului trecut, a fost ales un nou președinte, în persoana lui Faustin Archange Touadera, grupurile armate continuă să controleze majoritatea teritoriului național, în timp ce forțele armate, antrenate de consilieri militari ruși, au atacat, la 30 mai 2021, un post de control al frontierei cu Ciadul, ucigând șase soldați ciadieni și creând tensiuni cu țara vecină. În timpul ciocnirilor, trei instructori ruși au murit, consecință a exploziei unei mine. ${ }^{3} \mathrm{Ca}$ urmare a crizei create, prim-ministrul centrafrican și-a dat demisia, iar Franța şi-a suspendat ajutorul militar și financiar acordat acestei țări.

O situație aparte o reprezintă criza umanitară din zona Tigray, unde ciocnirile cu forțele militare etiopiene continuă, îndreptate cu precădere împotriva populației civile și unde, până în luna martie 2021, organizațiile umanitare internaționale și regionale nu au avut acces. Chiar dacă, în ultima perioadă, ONU a reuşit să asigure alimentele și medicamentele necesare pentru populația redislocată în cele patru zone de urgență, situația umanitară continuă să se înrăutățească, prin intervenția Eritreei în conflict, ceea ce a dus la apariţia insecurităţii alimentare, a înfometării populației locale și a creșterii numărului de îmbolnăviri, inclusiv cu virusul SARS-CoV-2. Responsabilii ONU atrag atenția asupra creșterii riscului apariției foametei, în Tigray și în unele zone din nordul Etiopiei, pentru sute de mii de persoane, ca urmare a împiedicării convoaielor umanitare de a asigura ajutoare populației locale și a transformării utilizării hranei și a medicamentelor în tehnici de război. Atât guvernul etiopian, cât și cel eritreean, acuză administrația Biden pentru sprijinul permanent acordat Mișcării de Eliberare a Poporului din Tigray (TPLF), considerată organizație teroristă, precum și pentru acțiunile de intimidare și amestec în afaceri interne, prin restricționarea vizelor unor oficialități din cele două țări.

Deși luptele din Sudan s-au oprit anul trecut, ca urmare a pericolului de contaminare cu COVID-19, încercările recente de reluare a discuțiilor de pace dintre guvernul interimar sudanez și liderii principalelor grupuri rebele, desfășurate

${ }^{2}$ Baba Ahmed, „Mali junta leader sworn in as president after 2nd coup”, Associated Press News, 7 iunie 2021, URL: https://apnews.com/article/africa-mali-government-and-politics60afe11f3629bc3440b4b2dab14e476a, accesat la 09.08.2021.

${ }^{3}$ Edith M. Lederer, „UN strongly condemned violations in Central African Republic”, Associated Press News, 8 iunie 2021, URL: https://apnews.com/article/united-nations-europe-africa-centralafrica-central-african-republic-6419b744546276d77498bc5a99b0614e, accesat la 11.06.2021. 
sub patronajul președintelui Sudanului de Sud, Salva Kiir, au eșuat și nu se întrevăd perspective pozitive în acest demers. Astfel, la începutul lunii iunie 2021, au reînceput luptele tribale dintre Taaisha și Falata în regiunea Darfur, din vestul Sudanului, soldate cu 36 de morți și 32 de răniți. ${ }^{4}$

Nici situația din zona Nilului Albastru nu este mai relaxată, după punerea în funcțiune, de către Etiopia, a Marelui baraj al Renașterii, intrând astfel într-o criză politică și de securitate cu Egipt și Sudan. Pentru a împiedica guvernul etiopian să umple bazinul barajului respectiv, diplomația egipteană caută să restabilească relațiile deteriorate cu Djibouti, pentru a-1 atrage de partea sa în disputa hidrografică din zonă. Deja au reușit să atragă atenția președintelui american Joe Biden despre un posibil conflict militar în zonă ca urmare a competiției pentru apă și să solicite intervenția comunității internaţionale pentru semnarea unui acord de folosire în comun a apei Nilului Albastru.

Erupția din luna mai a vulcanului Nyiragongo în apropierea orașului Goma, situat în estul Republicii Democrate Congo, a înrăutățit, de asemenea, situația umanitară și medicală precară din zonă, ucigând 32 de localnici și distrugând peste 500 de case. Valurile de lavă care au urmat au forțat 25.000 de locuitori să se redisloce în orașul Sake, situat în nord-vest, iar aproximativ 5.000 de civili au emigrat în Ruanda ${ }^{5}$. După prima decadă a lunii iunie, acești emigranți au început să se întoarcă acasă, sperând să-și găsească locuințele intacte.

Dar cea mai dezastruoasă situație din Africa de Nord și regiunea Sahel o reprezintă migrația ilegală, îndeosebi încercările disperate ale emigranților africani de a se deplasa intern în state africane mai stabile sau de a traversa Marea Mediterană și Oceanul Atlantic spre teritorii/insule aparținând unor state europene. În ultima perioadă, cele mai atractive zone pentru emigrare sunt enclava spaniolă Ceuta, din nordul Africii și insula Lampedusa, din sudul Italiei.

\section{Situația implementării acordului de încetare a focului în Libia}

Luna februarie 2021 a fost marcată de desfășurarea alegerilor în Libia, sub egida ONU, și instalarea unui guvern interimar de uniune națională începând cu martie 2021, condus de Abdul Hamid Dbeibah. Acest guvern are două obiective majore în agendă - implementarea acordului de încetare a focului semnat de beligeranți în luna octombrie 2020 și desfășurarea alegerilor generale, la 24 decembrie 2021.

4 Samy Magdy, „Report: Tribal clashes in Sudan's Darfur kill at least 36”, Associated Press News, 7 iunie 2021, URL: https://apnews.com/article/middle-east-africa-sudan456165e4b100419fa2308be478fa26ba, accesat la 11.06.2021.

${ }^{5}$ Jean-Yves Kamale, „Death toll from Conge volcano eruption rises to at least 32”, Associated Press News, 25 mai 2021, URL: https://apnews.com/article/world-news-africa-science-health-coronaviruspandemic-74ef0b8ec0c 838933ab625d80e538752, accesat la 28.05.2021. 
În ceea ce privește acordul de încetare a focului, una dintre prevederile sale esențiale stipulează retragerea tuturor luptătorilor străini și a mercenarilor din Libia, în termen de 90 de zile, dar nu precizează clar data de când se calculează acest termen - începând cu instaurarea guvernului interimar sau de la desfășurarea alegerilor generale. Ca urmare, ultimul raport al ONU precizează că nu s-a constatat nicio reducere în numărul de mercenari, estimați la peste 20.000 (sirieni, ruși, sudanezi și ciadieni), iar acțiunile de încălcare a embargoului impus de ONU privind transportul de arme către Libia continuă să aibă loc. Mai mult, se consideră că numărul luptătorilor străini ar fi crescut, precizând că ar exista, la sfârșitul lunii aprilie, 13.000 de sirieni și 11.000 de sudanezi în zonă $\breve{b}^{6}$.

Scopul retragerii luptătorilor străini și a mercenarilor este acela de a permite viitorului guvern liber ales să lupte contra terorismului. Acest deziderat reprezintă condiția de bază pentru redeschiderea misiunilor diplomatice ale marilor puteri în Tripoli, îndeosebi ale SUA și Italiei. Până în prezent, câteva state europene, printre care Franța și Grecia, și-au redeschis deja ambasadele în $\mathrm{Libia}^{7}$. La începutul lunii iunie și Spania a anunţat redeschiderea ambasadei sale la Tripoli, după şapte ani de întrerupere a relațiilor diplomatice dintre cele două țări. ${ }^{8}$ Acest eveniment s-a petrecut cu ocazia vizitei prim-ministrului spaniol, Pedro Sánchez, în capitala libiană, pe 4 iunie 2021.

Un Raport al Misiunii ONU de sprijin în Libia (UNSMIL) stabilită încă din anul 2011 prezintă că recent s-a început fortificarea unor așezări și construirea unor poziții de apărare în centrul Libiei, pe drumurile-cheie dintre orașul strategic Sirte, poarta de acces către marile câmpuri petrolifere și terminale portuare, și orașul Jufra. Raportul arată că „în ciuda angajamentelor asumate de părți, activitățile de transport aerian de marfă au continuat cu zboruri către diferite baze aeriene din regiunile vestice și estice ale Libiei”, iar ,datele indică faptul că nu s-a realizat nicio reducere a numărului luptătorilor străini sau a activităţilor lor în centrul Libiei”" Ca urmare a situației incerte, la 7 aprilie 2021, Secretarul General al ONU, Antonio Guterres, a prezentat o scrisoare către Consiliul de Securitate, în care a cerut iniţierea unei rezoluții care să grăbească părăsirea Libiei de către mercenarii și luptătorii străini, iar această activitate să fie monitorizată de 60 de observatori care să fie dislocaţi în cadrul misiunii UNSMIL.

\footnotetext{
${ }^{6}$ Noha Elhennawy, „Senior US diplomat in Libya to support interim government”, Associated Press News, 18 mai 2021, URL: https://apnews.com/article/middle-east-libya-africa-joe-bidenad3786c02e74bbb7b1d922b357afbc51, accesat la 25.05.2021.

${ }^{7}$ Ibidem.

${ }^{8}$ Noha Elhennawy, „Spain reopens its embassy in Libya after 7 years of closure”, Associated Press News, 3 iunie 2021, URL: https://apnews.com/article/libya-africa-europe-spain-middle-eastb802474d9e715be8bbf227 c040c3437, accesat la 09.06.2021

${ }^{9}$ Edith M. Lederer, „UN chief: Foreign fighters in Libya are violating cease-fire”, Associated Press News, 15 mai 2021,URL: https://apnews.com/article/united-nations-libya-africa-middle-eastf3a758d5ab63f21e71a50ee1c 95b9a8c, accesta la 15.05.2021.
} 
Una dintre cele mai dificile sarcini ale actualului guvern libian interimar va fi să convingă Turcia să-și retragă din zonă forțele militare și mercenarii sirieni pe care i-a angajat. Acordurile pe care guvernul turc le-a semnat cu cel libian, recunoscut de ONU (GNA), privind sprijinul militar acordat forțelor loiale de la Tripoli și noua delimitare a apelor teritoriale libiene în Marea Mediterană, în detrimentul Greciei și Ciprului, au avut la bază ipoteza prezenței militare turce în zonă pe termen lung. De altfel, președintele turc Recep Tayyip Erdogan a afirmat, în luna aprilie 2021, că a convenit cu prim-ministrul libian menținerea prevederilor controversatului acord maritim semnat în 2019, în schimbul acordării unui ajutor medical de 150.000 de doze de vaccin anti-COVID-19 și gestionarea de către Turcia a unui spital pentru combaterea pandemiei, în Tripoli. ${ }^{10}$ Intenția Turciei este de a înlocui prezența militară cu una politico-economică, încheind în acest sens cinci acorduri economice cu Libia pentru construirea unei centrale electrice și reîntoarcerea companiilor turcești în domeniul extragerii și producției de combustibil lichid.

La rândul ei, Rusia joacă pe două fronturi pentru a nu recunoaște implicarea sa activă în Libia. Pe de o parte, continuă să mențină în zonă Grupul de mercenari Wagner, loial guvernului de la Kremlin, iar pe de altă parte a votat rezoluția Consiliului de Securitate din 16 aprilie 2021 privind autorizarea celor 60 de monitori ONU care să-1 sprijine pe noul reprezentant special al Secretarului General al ONU în Libia, Ján Kubiš, să implementeze acordul de încetarea a focului din octombrie 2020 şi să eficientizeze embargoul împotriva traficului ilegal de arme, în vigoare de 10 ani.

Italia își menține interesul de reducere a numărului de imigranţi ilegali dinspre Nordul Africii și dorește să consolideze acordul militar pe care îl are cu Garda de coastă libiană privind eforturile de blocare a porturilor libiene și de întoarcere a imigranţilor care părăsesc coasta libiană cu ambarcațiuni improvizate. În acest scop, prim-ministrul italian Mario Draghi s-a întâlnit la Tripoli cu omologul său libian, la începutul lunii aprilie 2021, pentru a discuta reluarea relațiilor bilaterale și, mai ales, stoparea activităților grupurilor libiene de trafic de persoane și ale autorităților libiene de salvare umanitară în centrele de detenție ilegale. ${ }^{11}$ El a prezentat omologului său libian intențiile Uniunii Europene de a se implica mai eficient în stoparea traficului ilegal de persoane și în migrația ilegală spre Europa.

Președintele egiptean, Abdel Fattah al-Sisi, s-a întâlnit, de asemenea, cu prim-ministrul libian interimar nou ales, la Cairo, imediat după avizarea sa de către Camera Reprezentanților. Scopul întâlnirii a fost acela de a crește sprijinul puterilor

${ }^{10}$ Suzan Fraser, „Turkey, Libya recommit to contested maritime borders deal”, Associated Press News, 12 aprilie 2021, URL: https://apnews.com/article/turkey-libya-recep-tayyip-erdogan-tripoliankara-9faece0a5a1751c58df 7b6739318bff7, accesat la 17.05.2021.

11 Rami Musa, „In the first travel abroad, new Italian PM visits Libya”, Associated Press News, 6 aprilie 2021, URL: https://apnews.com/article/europe-africa-italy-libya-middle-east14fde11cc7caf013e34f67c17cae90d7, accesat la 30.05.2021. 
regionale pentru unificarea Libiei, prin încheierea unor parteneriate lărgite care să aducă proiecte economice egiptene în țară.

Sub presiunea SUA și restul puterilor regionale care s-au aflat în spatele uneia sau alteia din facțiunile rivale, precum Franța și Emiratele Arabe Unite, au confirmat oficial sprijinul diplomatic necondiționat pentru terminarea războiului civil din Libia și plecarea imediată a mercenarilor şi luptătorilor străini din zona de conflict. $\mathrm{Cu}$ toate acestea, traficul ilegal cu arme continuă să se desfășoare nestingherit către ambele părți beligerante din Libia, ceea ce duce la subminarea eforturilor de încetare a focului și încheierii unei păci stabile în regiune.

\section{Situația migranților din Nordul Africii}

Europa continuă să se confrunte și anul acesta cu un nou aflux de imigranți africani care încearcă să ajungă ilegal pe continent, traversând Marea Mediterană în ambarcațiuni atipice și necorespunzătoare navigării în ape internaționale. Mai mult, numărul mare de persoane care se îmbarcă pe astfel de nave depășește cu mult capacitatea de încărcare a ambarcațiunilor respective, iar furtunile care izbucnesc adesea în largul mării duc la scufundarea unora dintre ele și înecarea sau dispariția a numeroși migranți.

Eforturile întrunite ale navelor Gărzii de coastă libiene și cele ale Operației navale a UE „Irini” din apropierea coastelor libiene pentru împiedicarea plecărilor ilegale ale imigranților africani spre statele din sudul Europei și-au demonstrat doar parțial eficacitatea de la începutul acestui an. Astfel, așa cum precizează Organizația Internațională a Migrației (IOM), din cei peste 1.000 de emigranți ilegali plecați pe mare doar din Libia, un număr de nouă ambarcațiuni care transportau peste 800 de persoane ${ }^{12}$ au fost interceptate, iar emigranții au fost întorși în centre de detenție libiene. Din păcate, în prezent se contabilizează circa 11.000 de migranți africani în aceste centre de detenție, în care situația umanitară și siguranța oamenilor este precară.

De la începutul acestui an, surse mass-media arată că cele mai accesibile zone europene pentru emigrare au devenit enclava spaniolă Ceuta, din nordul Africii, și insula Lampedusa, din sudul Italiei. Astfel, în Italia au ajuns aproape 13.000 de imigranți africani, iar în enclava spaniolă Ceuta ${ }^{13}$ din Maroc au trecut aproape 8.000 de africani sub-saharieni, din care aproximativ 2.000 sunt minori. ${ }^{14}$ Și în cealaltă

\footnotetext{
$12 * * *$, ,UN agency: Libyan navy intercepts over 800 EU-bound migrants”, Associated Press News, 5 februarie 2021, URL: https://apnews.com/article/europe-africa-libya-middle-east-mediterraneansea-5a155e8c9df4b 7292ea66d3dd4fbbefc, accesat la 25.05.2021.

${ }^{13}$ N.A.: Enclava spaniolă Ceuta este un oraș spaniol de $20 \mathrm{~km}^{2}$ și 85.000 de locuitori, situat în Nordul Africii la țărmul Mării Mediterane și despărțit de Maroc printr-un gard dublu din plasă de sârmă înalt de 10 metri. Are statut de autonomie și este condus de președintele Juan Jesús Vivas.

${ }^{14}$ Vlad Mironescu, ,Copii morți aduși de valuri pe plajele din Libia, după ce ar fi încercat să ajungă în Europa”, Digi Tv, 26 mai 2021, URL: https://www.digi24.ro/stiri/externe/copii-morti-au-fost-adusi-
} 
enclavă spaniolă din regiune, Melilla, situată la 350 km est de Ceuta, au emigrat aproximativ 80 de africani. ${ }^{15}$ Iar sosirea anotimpului cald ar putea duce la creșterea numărului acestora. Ca urmare a relaxării pazei frontierelor de către grănicerii marocani, Armata spaniolă a redislocat trupe și vehicule blindate la granița cu Marocul, a intervenit în repetate rânduri și a întors jumătate din emigranți în Maroc. Oricum, situația actuală din enclavă s-a deteriorat până a ajuns cea mai mare criză umanitară, diplomatică și politică dintre Spania și Maroc, după disputa teritorială din 2002, iar liderii politici spanioli cred că situația a fost creată în mod special de Rabat, ca urmare a asistenței medicale acordate de către Spania lui Brahim Ghali, liderul Frontului Polisario, o mișcare de eliberare a teritoriului Sahara de Vest, sponsorizată de Algeria.

Încercarea disperată a emigranților africani de a părăsi ilegal coastele Nordului Africii și a scăpa de condițiile umilitoare umanitare din zonă, sub acțiunile clandestine ale traficanților de persoane, continuă să se soldeze cu un număr mare de persoane înecate și dispărute în apele Mării Mediterane. Conform datelor din proiectul privind dispariția migranților al IOM, anul acesta numărul persoanelor înecate sau dispărute în Marea Mediterană este de 827, mult mai mare decât cel de anul trecut, iar 691 de migranți s-au înecat în zona centrală a mării (a se vedea Figura nr. 1) ${ }^{16}$.

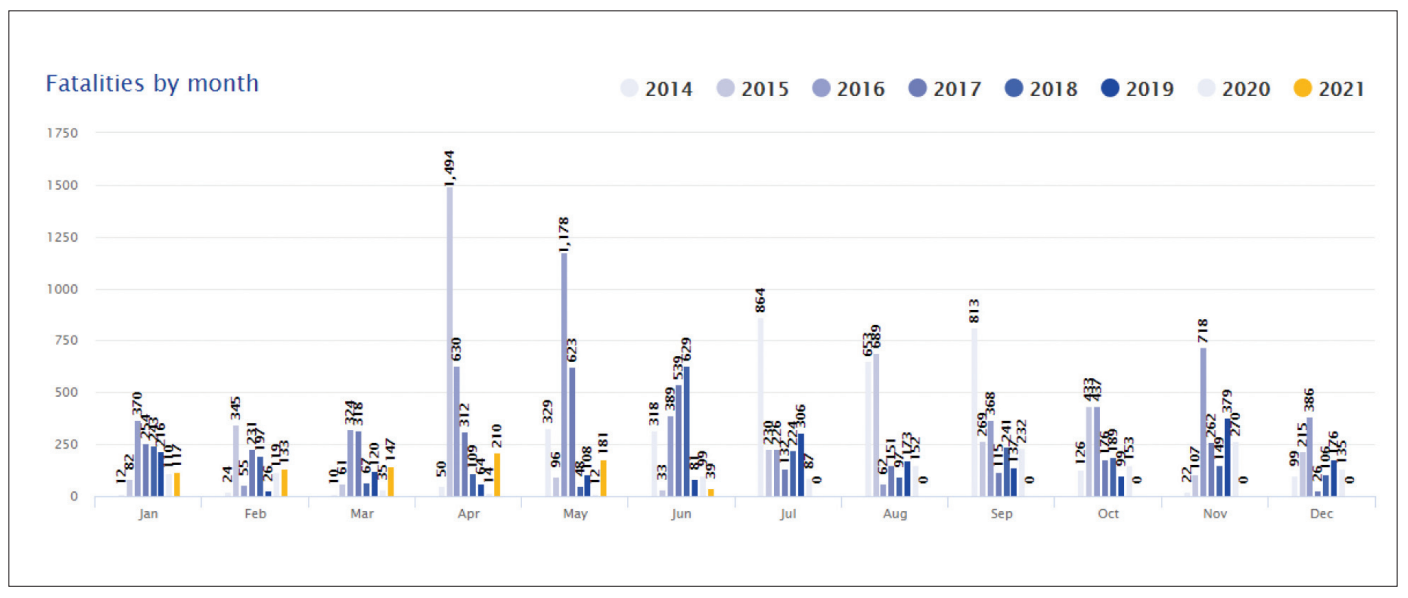

Figura nr. 1: Situația persoanelor înecate în Marea Mediterană în perioada 2014-2021 ${ }^{17}$

de-valuri-pe-plajele-din-libia-sustine-o-organizatie-caritabila-1541849, accesat la 31.05.2021.

${ }^{15}$ Renata Brito, Aritz Parra, „Spain, Marocco square off after 8,000 migrants arrive by sea”, Associated Press News, 18 mai 2021, URL: https://apnews.com/article/spain-europe-africa-morocco-migration9833744a70 58cc9438a8d7417d2944c6, accesat la 27.05.2021.

16 Proiectul privind dispariţia migranților pe principalele rute din Marea Mediterană este o iniţiativă a Organizației Internaționale pentru Migranți (OIM) începută în 2013, în cadrul Agendei 2030 pentru susținerea dezvoltării, iar datele sunt înscrise pe site-ul https://missingmigrants.iom.int/region/ mediterranean?, accesat la 25.06.2021.

${ }^{17}$ Sursa: https://missingmigrants.iom.int/region/mediterranean? 
Un prim eveniment s-a petrecut pe 19 ianuarie, când o barcă care transporta imigranți ilegali spre Europa s-a scufundat în apropierea coastelor libiene, soldându-se cu 43 de persoane înecate, toți bărbați din statele din Vestul Africii. La sfârșitul lunii martie 2021, o altă ambarcațiune s-a scufundat în apropierea coastelor libiene, soldându-se cu cinci morți ( 2 femei și 3 copii) și 77 de migranți au fost salvați de Garda de coastă libiană și reîntorși în centre de detenție. ${ }^{18}$ In luna aprilie a avut loc cel mai tragic accident naval de la începuturile migrației ilegale din Nordul Africii, în care și-au pierdut viața cel puțin 130 de persoane. La începutul lunii mai 2021, cel puțin 11 migranți ilegali s-au înecat când o barcă de cauciuc, transportând 20 de persoane, s-a răsturnat ${ }^{19}$, iar pe data de 9 mai 2021, o ambarcațiune cu 66 de persoane la bord s-a răsturnat, de asemenea, în apropierea coastelor libiene, 24 de africani înecându-se și 42 fiind salvați de Garda de coastă libiană și transportați la Tripoli. ${ }^{20}$

Însă nu doar Marea Mediterană a avut parte de astfel de accidente maritime. Pe 13 iunie 2021, o barcă cu 200 de emigranți din Cornul Africii, care a pornit din Djibouti, s-a răsturnat în apropierea coastelor Yemenului, toți cei care se aflau la bord fiind dați dispăruți. De la începutul anului, încă 40 de migranți s-au înecat în apropierea coastelor din Djibouti. ${ }^{21}$

Toate aceste evenimente nefericite au determinat reprezentanții IOM să solicite statelor europene riverane Mării Mediterane să analizeze situația creată și să redisloce capabilități navale de căutare-salvare în zonă.

\section{Impactul situației nord-africane asupra securității regionale și europene}

Situațiile de criză, conflictele în derulare și dezastrele umanitare din unele state africane situate în Nordul Africii și în regiunea Sahel, care au continuat și în prima jumătate a anului 2021, au deteriorat și continuă să deterioreze simțitor securitatea regională și europeană. Mai mult, lipsa acută de vaccinuri anti-COVID-19 și de personal medical specializat în zonă amplifică insecuritatea economică și sanitară a statelor africane, iar intensificarea activităților de trafic ilegal de imigranți africani spre sudul Europei afectează și mai mult securitatea europeană, deteriorând relațiile

\footnotetext{
${ }^{18}$ Samy Magdy, „UN: 2 women, 3 children drown in shipwreck off Libya’s coast”, Associated Press News, 31 martie 2021, URL: https://apnews.com/article/europe-north-africa-drownings-libya-africaeda22245e6ddb9543 b41a457bf2cc2fb, accesat la 27.04.2021.

$19 * * *$, „UN agency: Libyan navy intercepts over 800 EU-bound migrants”, p. 2.

${ }^{20}$ Samy Magdy, „UN: Migrant boat capsized off Libya; 2 dozen prezumed dead”, Associated Press News, 10 mai 2021, URL: https://apnews.com/article/world-news-united-nations-libya-africamiddle-east-111ea2236cf6b278 d49c5fc1201d67cd, accesat la 25.05.2021.

${ }^{21}$ Ahmed Al-Haj, „Officials: Migrant boat capsizes off Yemen, some 200 missing”, Associated Press News, 14 iunie 2021, URL: https://apnews.com/article/middle-east-yemen-africa-immigrationhealth-fcd4add84264d9add 649d8351cdb2bc6, accesat la 16.06.2021.
} 
diplomatice dintre state.

Astfel, pe lângă criza spaniolo-marocană creată de situația din enclava spaniolă Ceuta, o criză diplomatică a apărut și între Maroc și Germania, ca urmare a sprijinirii mișcării de eliberare din Sahara de Vest atât pe plan internațional, cât și cu informații, dar și a subminării implicării regionale a Rabatului în soluționarea războiului civil din Libia, prin neinvitarea Marocului la discuțiile de pace de la Berlin, din ianuarie 2021. Drept urmare, la începutul lunii mai 2021, ambasadorul marocan la Berlin a fost rechemat în țară, iar relațiile diplomatice dintre cele două țări au înghețat. ${ }^{22}$

Imposibilitatea rezolvării disputei privind împărțirea volumului de apă al Nilului Albastru între Egipt, Sudan și Etiopia, în urma începerii umplerii barajului „Marii Renașteri etiopiene" și eșuarea tratativelor diplomatice conduse de SUA pe acest subiect, i-a determinat pe liderii de la Cairo și Khartoum să solicite implicarea Uniunii Africane (UA) în această dispută cu tendințe de transformare într-un conflict regional și posibilitate de deteriorare a situației de securitate din Cornul Africii. Dar Summitul Uniunii Africane din luna aprilie 2021 privind securitatea apei în zonă nu a avut efectul scontat, chiar dacă toate statele arabe și-au arătat solidaritatea față de poziția egipteano-sudaneză. Ca urmare, AU a solicitat implicarea urgentă a Consiliului de Securitate al ONU în această dispută, pentru a începe un amplu proces de negociere în vederea încheierii unui acord tripartit. ${ }^{23}$

Unul dintre cele mai dezastruoase atacuri teroriste din ultimii ani a avut loc, la începutul lunii iunie 2021, în Burkina Faso. Insurgenții jihadiști, afiliați la Al-Qaida și gruparea Stat Islamic, au atacat populația locală din satul Solhan, ucigând cel puțin 132 de civili și incendiind locuințele acestora. ${ }^{24}$ Tot în luna iunie, un sinucigaș islamist aparținând grupului extremist al-Shabab, afiliat al-Qaida, s-a aruncat în aer într-un centru militar de instruire din Mogadishu, ucigând 15 oameni și rănind alți $20 .{ }^{25}$

Și situația internă de securitate din Vestul Africii a avut anul acesta de suferit. De la începutul acestui an, șase răpiri din instituții de învățământ au avut loc în nordul Nigeriei și în Niger din motive de răscumpărare, dintre care trei au fost

$22 * * *$, ,Morocco recalls its ambassador to Germany as tensions rise”, Associated Press News, 6 mai 2021, URL: https://apnews.com/article/europe-germany-africa-morocco-government-and-politicsf1d59cf3edaa36f368b15a58d8b53eca, accesat la 22.05.2021.

${ }^{23}$ Samy Magdy, „Arab League backs calls for UN intervention in the dam dispute”, Associated Press News, 6 mai 2021, URL: https://apnews.com/article/arab-league-united-nations-europe-africamiddle-east-5fd51629f3158 936afe3fae2da69f5b0, accesat la 15.06.2021.

${ }^{24}$ Sam Mednick, „Death toll rises after Burkina Faso village attack”, Associated Press News, 7 iunie 2021, URL: https://apnews.com/article/world-news-islamic-state-group-burkina-faso-africareligion-2430cbdf4e324f49e20612e94ba5a800, accesat la 14.06.2021.

25 Hassan Barise, „Suicide bomber kills at least 15 at Somalia military site”, Associated Press News, 15 iunie 2021, URL: https://apnews.com/article/somalia-suicide-bomber2d3c682a38bbb75eb1cd3dbc89f26810, accesat la 16.06.2021. 
violente și s-au soldat cu opt morți. ${ }^{26}$

Continuarea atacurilor teroriste din regiunea Sahel, chiar în pofida extinderii pandemiei de coronavirus, a obligat Franța să-și regândească politica africană, îndeosebi continuarea intervenției militare în zonă. Chiar dacă ultimele intervenții militare franceze s-au soldat cu un real succes, prin uciderea liderului jihadist Baye ag Bakabo al grupării al-Qaida din zonă, președintele francez Emmanuel Macron a precizat că, până la sfârșitul lunii iunie 2021, Parisul va termina operația „Barkhane”, pe care o va înlocui cu o altă operație militară de luptă împotriva extremiștilor islamiști din zonă, bazată pe o participare crescută din partea partenerilor. În total, prezența militară franceză în regiunea Sahel se va reduce simțitor. ${ }^{27}$

Situația economică precară din Tunisia, care a dus la lipsa locurilor de muncă, la șomajul crescut în rândul tinerilor și la diminuarea activităților turistice, amplificată de carantina prelungită în întreaga țară pentru oprirea răspândirii pandemiei de coronavirus, s-a concretizat la începutul acestui an prin demonstrații civile de anvergură și de durată, îndreptate împotriva Parlamentului din Tunis. Începute inițial în capitală, demonstrațiile s-au extins și în alte orașe precum Kasserine, Gafsa, Sousse și Monastir, devenind, pe zi ce trece, din ce în ce mai violente cocteiluri Molotov, spargeri, vandalizări de magazine și ciocniri cu forțele de ordine. În încercarea de a rezolva situația creată prin forță, autoritățile au recurs la Armată, folosind gaze lacrimogene și arestând sute de manifestanți. Criza socială l-a obligat pe prim-ministrul tunisian, Hitchem Mechichi, să-și revizuiască propriul Cabinet, unii miniștrii din acesta fiind considerați corupți sau suspectați de astfel de acte..$^{28}$

Situația incertă privind delimitarea apelor teritoriale, a zonelor contigue și a zonelor economice exclusive în bazinul Mării Mediterane, amplificată de traficul ilegal de africani care continuă să migreze spre insulele grecești și să solicite azil, continuă să întrețină criza politico-militară dintre Turcia și Grecia. Chiar dacă există un acord de reducere a migrației, semnat în 2016 între UE și Turcia, numărul de imigranți ilegali care ajung pe coastele insulelor grecești venind din Turcia este tot ridicat. Ca urmare, și în pofida presiunii pe care UE o pune asupra Atenei pentru gestionarea acordării de azil imigranților în interiorul țării, liderii greci au decis să solicite Ankarei analizarea cererilor de azil pentru imigranții veniți din Siria, Afganistan, Pakistan, Bangladesh și Somalia și să nu îi mai trimită spre Europa.

${ }^{26}$ Sam Olukoya, „1 student fatally shot in new abduction in Nigeria's north”, Associated Press News, 11 iunie 2021, URL: https://apnews.com/article/africa-nigeria-shootingscf0591261074099da45365fd6859760b, accesat la 15.06.2021.

${ }^{27}$ Edith M. Lederer, „UN envoy: More insecurity in Mali will have 'drastic' impact”, Associated Press News, 15 iunie 2021, URL: https://apnews.com/article/united-nations-mali-europe-africac66fb06c992ff6fd5435c973dbaa6eb7, accesat la 16.06.2021.

${ }^{28}$ Bouzza Ben Bouzza, „Tunisians protest arrests; government faces confidence vote”, Associated Press News, 26 ianuarie 2021, URL: https://apnews.com/article/north-africa-cabinets-tunisiacoronavirus-pandemic-africa-819dbd16717fe092a16fa18e1dac57ea, accesat la 15.04.2021. 
Mai mult, au cerut Turciei să primească înapoi 1.453 de emigranți intraţi ilegal în Grecia de la începutul anului 2021, fapt ce nu s-a întâmplat până în prezent. ${ }^{29}$

În urma acestei inactivități a liderilor turci, poliția de frontieră greacă a început să folosească o rețea automată de supraveghere de înaltă tehnologie, precum ,tunul cu sunet" cu bătaie lungă, bariere digitale, senzori și camere cu bătaie mare și vedere nocturnă, sisteme inteligente de analiză și detectoare de minciuni, identificarea biometrică prin scanare de palmă, mașini autonome pentru interviuri, integrarea datelor satelitare obținute de la drone terestre, aeriene, maritime și subacvatice și a trecut la construcția unui gard de oțel similar celui de la granița SUA - Mexic. Investițiile, în valoare de circa 3 miliarde de euro, au fost finanțate cu bani europeni, iar Grecia a cerut liderilor europeni să transforme misiunea de protecție a granițelor Europei de Sud „Frontex” într-o forță multinațională de securitate cu drepturi depline, care să patruleze în afara apelor teritoriale ale statelor membre şi să oprească fenomenul migrației ilegale dinspre Orientul Mijlociu și Nordul Africii (MENA).

\section{Concluzii}

Prima parte a anului 2021 a debutat cu o ameliorare a unor situații conflictuale din Nordul Africii și din regiunea Sahel (Libia, Sudan), dar și cu continuarea unora mai vechi sau chiar amplificarea lor (Mali, Tigray/Etiopia, Republica Centrafricană, Somalia). Al doilea an de pandemie în Africa, precum și intervențiile politicomilitare ineficiente și haotice ale organizațiilor internaționale și ale unor puteri regionale nu au reușit să gestioneze principalele cauze ale acestor conflicte și nici nu au ajutat guvernele statelor africane să facă față situațiilor create.

Situația pandemică dificilă a continuat îndeosebi în centrul și sudul Africii și a fost amplificată de lipsa personalului medical calificat și, mai ales, de lipsa unei cantități suficiente de vaccinuri în regiune. Astfel, țări precum Africa de Sud au reintrat în carantină totală, iar statele din Nordul Africii au continuat să implementeze măsuri anti-COVID-19, ineficiente din cauza slabei aprovizionări internaționale cu vaccinuri și medicamente.

$\mathrm{Nu}$ trebuie uitat nici faptul că, în plin secol al XXI-lea, se desfășoară, sub ochii comunității internaționale, o purificare etnică în regiunea Tigray, unde autoritățile etiopiene și cele din Eritreea și-au dat mâna pentru a șterge de pe fața pământului această etnie/trib, fie prin alungare și genocid, fie prin înfometare, care tot la genocid duce.

Schimbarea politicilor UE privind migrația ilegală a dus la creșterea numărului de victime ale mării și traficanților ilegali de persoane. Mai mult, cheltuirea fondurilor

${ }^{29}$ Derek Gatopoulos și Costas Kantouris, „In post-pandemic Europe, migrants will face digital fortress", Associated Press News, 31 mai 2021, URL: https://apnews.com/article/middle-east-europemigration-technology-health-c23251bec65ba45205a0851 fab07e9b6, accesat la 17.06.2021. 
europene pe mijloace tehnologice avansate care să protejeze accesul emigranţilor la granița de est a Europei, cât și retragerea navelor și aeronavelor de căutare-salvare din zonele des traversate de vasele improvizate ale migranților africani nu au avut efectul scontat de a descuraja traversadele acestor vase și încercările disperate ale migranților de a forța intrarea ilegală în insulele grecești. Noua strategie europeană mai agresivă privind antimigrația a avut ca efecte secundare critici dure din partea vecinilor UE, precum și apariția unor crize diplomatice între unele state riverane Mării Mediterane - Spania-Maroc, Grecia-Turcia etc. Un alt efect care s-ar putea să apară în viitorul apropiat îl reprezintă îngrijorările din punctul de vedere al eticii măsurilor întreprinse, care pot duce la adâncirea autocrației europene și cele privind posibilitatea accesării noilor tehnologii utilizate la granițele UE de către state nemembre.

Un pas important în direcția revederii politicilor europene 1-a întreprins Danemarca prin aprobarea, la începutul lunii iunie 2021, a deschiderii unui centru de recepție al emigranților într-o țară africană, unde să se desfășoare procesul de verificare a cererilor de azil către această țară. Sunt în discuție țări precum Ruanda, cu care Danemarca are deja semnat un Memorandum de înțelegere (MoU) din luna aprilie 2021, dar și Tunisia, Etiopia sau chiar Egipt. Aceeași procedură au solicitat-o și grecii liderilor turci de la Ankara, pentru a analiza și aviza cererile de azil ale refugiaților din MENA înainte de a fi trimiși către Europa. Dar solicitarea lor a rămas, deocamdată, fără răspunsul scontat.

Situația de insecuritate din Nordul Africii și regiunea Sahel cauzată de conflicte nerezolvate, crize interetnice/tribale, răspândirea pandemiei de coronavirus, acțiuni teroriste și ale grupărilor de trafic ilegal cu arme, persoane și droguri, foamete și sărăcie, continuă să-și arate efectele negative asupra statelor africane din regiune, dar și asupra relațiilor cu vecinii europeni. La rândul lor, măsurile politice, diplomatice, economice și militare întreprinse de statele europene și organizațiile internaționale în Africa pentru a gestiona situaţia existentă sunt ineficiente și discordante, amplificând crizele/conflictele din zonă în loc să le soluționeze. Toate aceste efecte negative au dus la apariția disensiunilor și chiar a crizelor dintre anumite state și chiar în rândul ONU, UA și UE.

\section{BIBLIOGRAFIE:}

1. ***, ,Proiectul Organizației Internaționale pentru Migranți (IOM) privind dispariția migranților pe principalele rute din Marea Mediterană, URL: https:// missingmigrants.iom.int/region/mediterranean?

2. ***, ,Morocco recalls its ambassador to Germany as tensions rise”, Associated Press News, 6 mai 2021, URL: https://apnews.com/article/europe-germany-africamorocco-government-and-politics-f1d59cf3edaa36f368b15a58d8b53eca 
3. ***, „UN agency: Libyan navy intercepts over 800 EU-bound migrants”, Associated Press News, 5 februarie 2021, URL: https://apnews.com/article/europeafrica-libya-middle-east-mediterranean-sea-5a155e8c9df4b7292ea66d3dd4fbbefc

4. AL-HAJ, Ahmed, „Officials: Migrant boat capsizes off Yemen, some 200 missing", Associated Press News, 14 iunie 2021, URL: https:// apnews.com/article/middle-east-yemen-africa-immigration-healthfcd4add84264d9add649d8351cdb2bc6

5. AHMED, Baba, „Mali junta leader sworn in as president after 2nd coup”, Associated Press News, 7 iunie 2021, URL: https://apnews.com/article/africa-maligovernment-and-politics-60afe11f3629bc3440b4b2dab14e476a

6. BARISE, Hassan, „Suicide bomber kills at least 15 at Somalia military site”, Associated Press News, 15 iunie 2021, URL: https://apnews.com/article/somaliasuicide-bomber-2d3c682a38bbb75eb1cd3dbc89f26810

7. BEN BOUAZZA, Bouazza, „Tunisians protest arrests; government faces confidence vote", Associated Press News, 26 ianuarie 2021, URL: https:// apnews.com/article/north-africa-cabinets-tunisia-coronavirus-pandemic-africa819dbd16717fe092a16fa18e1dac57ea

8. BRITO, Renata; PARRA, Aritz, „Spain, Marocco square off after 8,000 migrants arrive by sea", Associated Press News, 18 mai 2021, URL: https:// apnews.com/article/spain-europe-africa-morocco-migration-9833744a7058 cc9438a8d7417d2944c6

9. ELHENNAWY, Noha, „Senior US diplomat in Libya to support interim government", Associated Press News, 18 mai 2021, URL: https://apnews.com/ article/middle-east-libya-africa-joe-biden-ad3786c02e 74bbb7b1d922b357afbc51

10. ELHENNAWY, Noha, „Spain reopens its embassy in Libya after 7 years of closure", Associated Press News, 3 iunie 2021, URL: https://apnews.com/article/ libya-africa-europe-spain-middle-east-b802474d9e715be8bbf2227c040c3437

11. FRASER, Suzan, „Turkey, Libya recommit to contested maritime borders deal",AssociatedPressNews, 12aprilie2021,URL:https://apnews.com/article/turkeylibya-recep-tayyip-erdogan-tripoli-ankara-9faece0a5a1751c58df7b6739318bff7

12. GATOPOULOS, Derek; KANTOURIS, Costas, „In post-pandemic Europe, migrants will face digital fortress", Associated Press News, 31 mai 2021, URL: https://apnews.com/article/middle-east-europe-migration-technology-healthc23251bec65ba45205a0851fab07e9b6

13. KAMALE, Jean-Yves, „Death toll from Conge volcano eruption rises to at least 32", Associated Press News, 25 mai 2021, URL: https:// apnews.com/article/world-news-africa-science-health-coronavirus-pandemic74ef0b8ec0c838933ab625d80e538752

14. LEDEREE, Edith M., „UN focuses on demand to repatriate foreign fighters in Libya", Associated Press News, 30 apilie 2021, URL: https://apnews. 
com/article/united-nations-libya-europe-africa-middle-east-5746eb32c1 f3ac676d $8 \mathrm{f} 37$ dacec3213c

15. LEDEREE, Edith M., „UN chief: Foreign fighters in Libya are violating cease-fire", Associated Press News, 15 mai 2021,URL: https://apnews.com/article/ united-nations-libya-africa-middle-east-f3a758d5ab63f21e71a50ee1c95b9a8c

16. LEDEREE, Edith M., „UN strongly condemned violations in Central African Republic", Associated Press News, 8 iunie 2021, URL: https://apnews. com/article/united-nations-europe-africa-central-africa-central-african-republic6419b744546276d77498bc5a99b0614e

17. LEDEREE, Edith M., „UN envoy: More insecurity in Mali will have 'drastic' impact', Associated Press News, 15 iunie 2021, URL: https://apnews.com/ article/united-nations-mali-europe-africa-c66fb06c992ff6fd5435c973dbaa6eb7

18. MAGDY, Samy, „UN: 2 women, 3 children drown in shipwreck off Libya's coast", Associated Press News, 31 martie 2021, URL: https:/apnews.com/article/ europe-north-africa-drownings-libya-africa-eda22245e6ddb9543b41a457bf2cc2fb

19. MAGDY, Samy, „Arab League backs calls for UN intervention in the dam dispute", Associated Press News, 6 mai 2021, https://apnews.com/article/arab-leagueunited-nations-europe-africa-middle-east-5fd51629f3158936afe3fae2da69f5b0

20. MAGDY, Samy, „UN: Migrant boat capsized off Libya; 2 dozen prezumed dead", Associated Press News, 10 mai 2021, URL: https:// apnews.com/article/world-news-united-nations-libya-africa-middle-east111 ea2236cf6b278d49c5fc1201d67cd

21. MAGDY, Samy, „Report: Tribal clashes in Sudan's Darfur kill at least 36”, Associated Press News, 7 iunie 2021, URL: https://apnews.com/article/middle-eastafrica-sudan-456165e4b100419fa2308be478fa26ba

22. MEDNICK, Sam, „Death toll rises after Burkina Faso village attack”, Associated Press News, 7 iunie 2021, URL: https://apnews.com/article/worldnews-islamic-state-group-burkina-faso-africa-religion-2430cbdf4e $324 \mathrm{f} 49 \mathrm{e} 20612 \mathrm{e}$ 94ba5a 800

23. MIRONESCU, Vlad, „Copii morți aduși de valuri pe plajele din Libia, după ce ar fi încercat să ajungă în Europa”, Digi Tv, 26 mai 2021, URL: https:// www.digi24.ro/stiri/externe/copii-morti-au-fost-adusi-de-valuri-pe-plajele-dinlibia-sustine-o-organizatie-caritabila-1541849

24. MUSA, Rami, „In the first travel abroad, new Italian PM visits Libya”, Associated Press News, 6 aprilie 2021, URL: https://apnews.com/article/europeafrica-italy-libya-middle-east-14fde11cc7caf013e34f67c17cae90d7

25. OLUKOYA, Sam, „1 student fatally shot in new abduction in Nigeria's north”, Associated Press News, 11 iunie 2021, URL: https://apnews.com/article/ africa-nigeria-shootings-cf0591261074099da45365fd6859760b 